\title{
7
}

\section{HUME AS MORALIST: A SOGIAL HISTORIAN'S PERSPECTIVE}

\section{Nicholas Phillipson}

In this paper I want to discuss David Hume's views about morals, politics and citizenship and the role of philosophers and philosophizing in modern civil society - what I shall call his theory of civic morality. ${ }^{1}$ This is a subject which has been neglected by philosophers, presumably because it is of limited philosophical interest. But it is of considerable interest to the historian who wants to understand Hume's development as a philosopher, to locate his thought within a specific, Scottish context and to arrive at some understanding of his surprisingly close and cordial relations with the literary and social world of enlightened Edinburgh. These are large claims and I cannot hope to substantiate them fully in a short paper. My purpose is first, to show that, historically speaking, Hume's preoccupation with civic morality was of central rather than peripheral interest to him as a philosopher and that it helps to explain his otherwise rather puzzling decision to give up philosophizing systematically in the manner of Hobbes and Locke, in favour of polite essay-writing in the manner of Addison and Steele. My second purpose is to suggest that Hume's interest in civic morality, his neo-Addisonian (or perhaps I should say, neoCiceronian) mode of philosophizing about it and the nature of his understanding of politics, citizenship and philosophizing in a modern age was, unlike his thought about religion, 
responsive to and consonant with some of the most important ideological preoccupations of his Scottish contemporaries. It was, I suspect, a shared interest which helped to contain some of the anxieties Hume's notorious religious scepticism caused his contemporaries. Without it, he could not possibly have emerged as one of the leaders of Edinburgh's intellectual life in the age of the Scottish Enlightenment.

Hume's Treatise was completed in I740. It was his first and last exercise in constructing a comprehensive, systematic science of man. For much of the next decade he was to become immersed in essay-writing in the distinctive and fashionable manner of Addison and Steele's Spectator. The Addisonian essay was more than a literary genre. It was a vehicle for moralizing about human behaviour in a distinctive way and by Hume's day it had come to hold peculiar ideological associations for Scotsmen. In adopting it, therefore, Hume was allowing himself to be drawn into a distinctive ideological world. Addison and Steele had written for an audience of men and women of rank, property and position in local and national life, who were preoccupied with questions of social role, personal conduct and private happiness in an increasingly complex, commercially orientated society. ${ }^{2}$ How was one to achieve virtue and happiness in the turbulent world of courtiers, fops, pedants and speculators? Addison and Steele answered that it was to be found in the private world of family and close friends, not in the public world of affairs. It was only in a sociable but private world that one could hope to avoid the buffetings of fortune and acquire a sense of moral stability and a sense of ego. And without that, one could not hope to adapt oneself to a rapidly changing world with any ease and self-respect. But that private world was one which had, so to speak, to be constructed. Men and women had to learn to redirect their expectations of life from the public to the private world. They had to learn to detach themselves from society and to be spectators of it as well as actors in it. They even had to learn to cultivate the art, which Adam Smith was later to discuss with such uncanny skill, of seeing themselves as others 
saw them. A private world, in which men felt at ease with each other and acquired a sense of virtue was one whose inhabitants had learned to defer to each other's tastes and opinions, to value consensus as well as truth in their discussion of ideas and things. In such a world conversation meant learning to discuss one's ideas and observations not simply in order to inform one's friends but to be sure that one's own understanding was as free as possible of affectation, idiosyncracy and personal prejudice. For Addisonian moralizing was based on the assumption that the form a man's actions took depended on the nature of his beliefs and that those beliefs were embodied in a distinctive frame of mind (it was a phrase Addison seems to have invented) ${ }^{3}$ which could be regulated by means of self-criticism, detachment and a desire to cultivate private virtues of friendship and family affection. Only thus could one hope to acquire a sense of virtue.

Addison and Steele's essays were read throughout the Western world in the eighteenth-century - indeed they are one of the seminal influences on Western taste and manners and it would have been extraordinary if they had been ignored in Edinburgh, where they were read, discussed and imitated throughout the century. ${ }^{4}$ Contemporary historians invariably dated the revival of letters in Scotland from the date of their publication and in another paper I would be prepared to argue that they played an important part in encouraging the Scots to take an interest in manners, morals and society. What is curious and of relevance to this discussion is that although the Scots clearly had a voracious appetite for Addisonian moralizing, their interest was of a peculiar kind. For while Addison and Steele had only a passing interest in the public consequences of the improvement of manners, the Scots thought that was a matter of cardinal importance. The proceedings of the many clubs and societies which were devoted to the improvement of manners according to Addisonian principles, like the writings of Allan Ramsay, the first Scottish Addison, make it clear that they believed that the improvement of private morality was a matter of public 
importance to be undertaken by every patriotically-minded Scotsman anxious to revive the civic virtue of his country. Those who undertook the job, therefore, could be regarded as good patriots and virtuous citizens as well as decent men. ${ }^{5}$

As we shall see, this was a view with which Hume greatly sympathized and it is worth pausing, very briefly, to consider why the Scots should have attached so much civic importance to the improvement of manners. ${ }^{6}$ In the seventeenth and eighteenth centuries it was customary for political moralists in the Western world to hold the classical view that a nation's liberties, independence and identity was founded on her constitution, enshrined in her laws and political institutions and preserved by a virtuous citizenry. It was on such foundations that a nation's grandeur and her wealth and excellence in the arts and sciences rested. But the Scots had long been accustomed to think differently. It was difficult for them to believe that the preservation of the liberties and independence of their country had had much to do with her underdeveloped laws and political institutions. It was much more plausible to believe, as every historian and chronicler had assumed, that she owed her independence and identity to the warlike manners of the gothic barons who had kept the English at bay, and had ensured the survival of a weak monarchy and undeveloped laws and political institutions. In other words, as far as Scotsmen were concerned, their liberties were founded on the manners of the people and it was the job of virtuous citizens to use their political resources to work for their preservation. Just what that meant had become clear in 1707 when, faced with the prospect of an acute economic and political crisis, and the choice of preserving their parliament or exchanging it for the opportunity of free trade with the English, the Scots parliament reluctantly decided that free trade was of more importance to preserving their country's manners than parliament. And it was in order to exploit the advantages the Union offered to stimulate the patriotism and virtue of a new generation that societies of artistocrats, professional men and literati sprang up in post-union Edinburgh to improve 
the nation's manners by encouraging trade and learning. By Hume's day, Edinburgh which had once been the seat of the old Scots Parliament had become a city of para-parliamentary clubs and societies of patriotically minded men devoted to the regeneration of the manners of a fallen nation and improving the virtue of its citizens. Hume's Edinburgh was, in its own remarkable way, a city dedicated to the pursuit of virtue and, in the process, Addisonian morality became one of the principal engines for bringing about the regeneration of the nation's manners. In turning to Addisonian essay-writing, in other words, Hume was, consciously or unconsciously, trimming his sails to meet the prevailing ideological winds of Enlightened Edinburgh.

Hume's decision to give up philosophizing in the grand manner of the Treatise has always made historians and philosophers uneasy. And although the vulgar view that he simply took to essay-writing for fame and money was effectively refuted by Ernest Mossner, his own alternative explanation, that Hume wanted a popular vehicle for bringing his philosophy forward is underdeveloped. ${ }^{7}$ For a historian, however, Hume's decision to turn moralist is not altogether surprising. His interest in practical morality was long-standing. James Boswell reported that Hume had told him from his death-bed that he had been pious as a child. He had read The Whole Duty of Man and made 'an abstract from the catalogue of vices at the end of it, and examined himself by this, leaving out Murder and Theft and such vices as he had no chance of committing, having no inclination to commit them. This, he said, was strange work; for instance, to try, if, not withstanding his excelling his schoolfellows, he had no pride or vanity.'8 His first known letter, written to Michael Ramsay in 1727 when he was sixteen, speaks of the pleasure Cicero and Virgil gave him, which was all the greater for the relief they gave him from the anxieties of metaphysical speculation. 'The Philosophers Wiseman, and the Poets husbandman agree in peace of mind, in a Liberty \& Independancy on Fortune, \& Contempt of Riches, Power \& Glory' Hume wrote. 'Every- 
thing is placid \& quiet in both; nothing perturbd or disorderd ... My peace of Mind is not sufficiently confirmed by Philosophy to withstand the Blows of Fortune; This Greatness \& Elevation of Soul is to be found only in Study \& contemplation, this can alone teach us to look down upon humane Accidents.' At an early age Hume had become engrossed in problems of personal conduct and practical morality and had turned to Cicero, whose writings formed the cornerstone of Western thinking about civic morality. ${ }^{10}$ At the same time, his letter hints that he had already acquired what was to be a lasting interest in the nature of those moral beliefs which strike one as obviously attractive even though they do not appear to be founded on the principles of human nature.

Hume's long sojourn in a disturbing metaphysical wilderness, which seems to have begun in earnest around 1729, appears to have isolated him from the clubbable literary society to which he, almost more than any other eighteenthcentury philosopher, attached so much importance. He withdrew to the country, hovered on the edge of a nervous breakdown, left Scotland for Bristol and later La Flèche, where he wrote the first two parts of the Treatise. The crucial first volume of that protean work was, as an early reviewer unkindly put it, marred by egotisms. ${ }^{11}$ It possessed many of the epic qualities Sheldon Wolin has noticed in Hobbes' Leviathan. ${ }^{12}$ It was, as scholars have often noted, a quasi-autobiographical exploration of the mind, which raised as many questions as it answered, the tour de force of an extraordinary man who was in the process of resolving fundamental questions about the nature of philosophizing and his own role as a philosopher. It would have been reasonable for a contemporary to have asked what he was going to do next. Would he, like Thomas Reid, develop as a metaphysician and a student of perception? Would he develop, perhaps rather like Adam Smith, as a philosopher who was interested in the mechanics of the moral sense and the process of acquiring moral sentiments? Would his discussion of law and morality encourage him to take the 
quasi-anthropological path he later sketched out in essays like 'Of National Characters' or 'The Natural History of Religion?. He did none of these things. Instead, he decided to develop the central principles of the Treatise as a practical moralist anxious to reach an understanding of morality which was founded on the principles of human nature and not on the whims of a moralist. It was not an altogether surprising step. After all, he had told Francis Hutcheson that the principles of Cicero's Offices were never far from his mind while he was writing the Treatise. ${ }^{13}$

But perhaps the most interesting evidence that Hume's interests were moving, or perhaps returning to the paths of practical morality is to be found in the remarkable last chapter of the first book of the Treatise. Hume had been forced to the conclusion that it was impossible to avoid holding beliefs about events which had taken place in the external world. However, those beliefs could only properly be described as lively sensations which ascribed certainty rather than probability to the consequences of those events. What troubled him was that although these conclusions seemed inescapable if one reasoned from experience rather than final causes, they were completely at odds with the understanding of ordinary men and the teaching of all philosophy. It was a disturbing position for a sociable man to be in and it seemed to have generated existential anxieties in Hume's mind, for he recalled himself asking questions such as these: 'Where am I or what?' 'From what causes do I derive my existence and to what condition shall I return ... I am confounded with all these questions and begin to fancy myself in the most deplorable condition imaginable, inviron'd with the deepest darkness and utterly depriv'd of the use of every member or faculty.'14

Descartes had written of the existential anxieties his own early scepticism had aroused in much the same way and said he had resolved them by an act of mind. But Hume thought that although scepticism was 'a malady, which can never be radically cur'd' its debilitating intellectual and moral consequences could be brough under control by acquiring a 
frame of mind and adopting a manner of living which was broadly similar to that which Addison had recommended.15 The philosopher should remember that no matter to what sceptical conclusions he was driven by philosophy, Nature, in the form of the frame of mind men adopt in ordinary social life, would quickly expose their intellectual and moral limitations.

I dine, I play a game of back-gammon, I converse, and am merry with my friends; and when after three or four hours amusement, I wou'd return to these speculations, they appear so cold, and strain'd and ridiculous, that I cannot find in my heart to enter into them any farther. ${ }^{16}$

The company of friends, a willingness to be guided by the natural beliefs which govern the behaviour of men in society, not the intellect; that was the real cure for excessive scepticism. What is more it was only in society that philosophers could learn to observe human behaviour systematically and philosophize about it properly. The company of friends was thus a cure for bad philosophy as well as bad morals. In spirit at least, Hume's position was a thoroughly Addisonian one. ${ }^{17}$

Hume turned to the business of Addisonian moralizing immediately after completing the Treatise in 1740 . At first he and Lord Kames planned to produce a series of weekly essays exactly as Addison and Steele had done but the plan fell through. ${ }^{18}$ Instead Hume collected the essays he had already written, added a few more and published them in two volumes of Essays Moral and Political published in r741 and I 742. The preface to the first volume acknowledged debts to the Spectator and, interestingly, to the Craftsman, the first journal to attempt to bring political discussion into the world of polite morality. In this preface Hume promised to reflect with 'moderation' and 'impartiality' on political questions. These are key words in the Spectatorial vocabulary. The spectator could be expected to distance himself from the world, reflect on its follies and philosophize about them. And just as Addison had allowed a system of morality to evolve as the essays proceeded, so 
Hume set out gradually to build up a system of civic morality which would appeal to the sentiments as well as to the intellect of the polite men and women at whom it was directed. In so doing he would broaden the intellectual range of the Addisonian essay by drawing the attention of polite readers to the problem of civic morality that had arisen in a modern age and had been overlooked by contemporary moralists.

Hume's first volume was largely devoted to a discussion of the follies of the contemporary political world; the second was largely devoted to the role of philosophers and philosophizing in a modern age. ${ }^{19}$ Together they were designed to illustrate and develop the central thesis of Book III of the Treatise that liberty, commerce, refinement and progress in the arts and sciences only arose in countries with good laws and constitutions and were thus dependent upon them for their survival. ${ }^{20}$ Thus all morality was, in an important sense, civic morality and all learning and philosophy could be shown to rest upon civic foundations. In the first volume, most of Hume's time was devoted to a sceptical discussion of some of the most fundamental beliefs which Englishmen held about the constitution and contemporary politics. Assumptions about the antiquity of the constitution, French despotism and English liberty, the nature of liberty and authority itself, the role of political parties in a modern state, and the virtues and vices of a free press were all discussed critically and philosophically. In the Treatise he had argued that all we can ever know from experience about the nature of authority in civil society stems from our own experience of family and social life and depends on a recognition of the curious fact that we have a natural disposition to respect established authority. Thus all that we can have any reason to expect from government is that it will prescribe the rules of justice on which an orderly social life depends and do its best to maintain them. ${ }^{21}$ It was, he argued in the Essays, on such principles that we ought to discuss the merits of the English and French constitutions and evaluate the activities of political zealots who did not seem able to understand either the nature 
of our respect for established authority or the dangers which an excessive and abstract libertarian zeal posed for the preservation of an orderly social life. For it was Hume's primary principle of politics that 'Good laws may beget order and moderation in government, where the manners and customs have instilled little humanity or justice in the tempers of men.' ${ }^{22}$ It was on the rules of justice, supported by the authority of a government and the natural loyalties of the people that liberty, commerce, progress in the arts and sciences and social ease depended. No man who had learned to value the private virtues that Addison had extolled ought to forget the civic foundations upon which his private happiness rested and it was his duty to reflect on the civic duty he owed to the society of which he was part. It was not a debt which could safely be overlooked.

But how could it be repaid? Hume's answer was the one a civic moralist might have been expected to give - political participation; but it was political participation of a peculiar kind and one that was by no means so discordant with the principles of Addisonian morality as one might suppose. For Hume, too, believed that contemporary party politics posed a threat to human happiness. The reason was that it was geared to the pursuit of political objectives founded in antiquated prejudices which had little or nothing to do with the problems of maintaining political stability and the rules of justice in a modern age. Modern party politicians were factious zealots who posed almost as much of a threat to an orderly social life as religious enthusiasts. Thus civic virtue consisted in standing back from party political warfare and learning how to hold one's instinctive political enthusiasms in check by thinking of one's political duty in relation to the sole end of maintaining the rules of justice. To put it another way Hume had turned the liberty of indifference into a civic virtue.

In purely ideological terms, Hume's conception of civic virtue is of some interest to a Scottish historian. Scotsmen had already learned to believe that their country's future liberties and independence depended on their ability to im- 
prove its manners. Yet they knew that was only possible within the framework of a British constitution which was the source of the laws, government and the economic hopes upon which any future national regeneration depended and as North Britons they were required to believe that a nation's liberties rested on political foundations. Thus virtuously minded Scotsmen found themselves obliged to think in terms of loyalty to two nations and were required to subscribe to two very different ideologies. In the past no Scots theoretician had managed to construct a satisfactory model which would define the relations between the two kingdoms and the two conceptions of civic duty. In the long and complex debate about the desirability of an act of Union, Scottish writers had tended to gloss the problem and had assumed that in practical terms there was no reason why one should not learn to be an equally virtuous citizen of both countries. Only Andrew Fletcher of Saltoun, a fiery and important political moralist, well known both in England and Scotland, had got as far as hinting at the outline of a model which would define the place of Scotland in a modern kingdom and the relations between the two types of civic duty. His model, which was underdeveloped and largely inspirational in character, cannot be properly discussed here. ${ }^{23}$ In outline Fletcher saw Britain as a kingdom of regions or nations each of which was governed from local centres of power by a locally based and presumably landed élite.

So many different seats of government will highly encourage virtue. For all the same offices that belong to a great kingdom must be in each of them; with this difference, that the offices of such a kingdom being always burdened with more business than anyone can rightly execute, most things are abandoned to the rapacity of servants: and the extravagant profits of all great officers plunge them into all manner of luxury and debauch them from doing good: whereas the offices of the lesser governments extending only over a moderate number of people, will be duely executed, 
and many men have occasions to put into their hands of doing good to their fellow citizens. So many different seats of government will highly tend to the improvement of all arts and sciences; and afford great variety of entertainment to all foreigners and others of a curious and inquisitive genius as the cities of Ancient Greece did. ${ }^{24}$

Fletcher's model implied that a man's primary loyalty was to his nation or region and that his loyalty to the prince and the system of laws he embodied was somehow secondary. But so deeply did the irascible Fletcher dislike all princes and all systems of court government that he could not bring himself to think of Scotland as part of a larger kingdom which was governed by laws which had a positive role to play in the maintenance of Scottish liberties. By Hume's day, however, it was clear that politically minded Scotsmen had slipped quite easily and naturally into a pattern of political behaviour which implied ideas of primary and secondary loyalty. As I have already indicated, Edinburgh had become a city of clubs and societies which were para-parliamentary in character and dedicated to the enthusiastic pursuit of virtue by encouraging economic and cultural improvement in order to secure the all-important manners of the nation. In London, however, it was quite different. The forty-five Scots Members of Parliament and the sixteen Representative peers took almost no part in the party political warfare around which political life revolved, contenting themselves with offering passive support to whatever ministry was in power in exchange for pensions and places, only appearing on the active stage of Westminster politics when local or national interests were involved. ${ }^{25}$ In fact, by Hume's day the Scottish political community at large was behaving as Fletcher and Hume had advocated. It had cultivated a congenial and sometimes lucrative passive indifference to the politics of Britain as a whole and had sought virtue and happiness by actively cultivating what one might call the more private, domestic, national virtues. In purely Scottish terms what Hume had done was to show that this 
sort of political behaviour could be regarded as a source of potential civic virtue. But it was a conception of civic virtue that was much easier to understand in Edinburgh than in London, where, understandably, it helped to earn Hume the unflattering and wholly misleading title of Tory. ${ }^{26}$

But Hume was no ideologue, and interesting as his discussion of politics is as evidence of the consonance of his thinking about public affairs with that of politically minded Scotsmen, that was simply a by-product of his central purpose as a moralist. He wanted to show how intelligent and responsiblyminded men could acquire the frame of mind which would allow them to make a positive virtue out of political indifference and allow them to define the relationship between the public and private world in which they moved. This theme was sketched out in the first volume of essays and developed at greater length in the second. 'Good will or ill fortune is very little at our disposal' Hume had written, in a thoroughly Addison vein, in the first essay of the first volume, 'Of the Delicacy of Taste and Passion'. Unless we appreciated the folly of pinning all our hopes and fears on external events over which we had little control, we would be unable to achieve any sort of moral control over our lives and our happiness. The key to acquiring a sense of moral autonomy lay in cultivation of the arts and sciences. This was something which everyone could pursue in private at will. It would help men to forget about the bustle of the public world and encourage them to study human behaviour and reflect on the principles which governed its operations. If this was done seriously on the basis of observation and experience and not on the assumption that events ought to be explained in terms of final causes, it would teach men to value intellectual modesty and encourage them to moderate their enthusiasms and unreasonable expectations of life. It would also produce 'an agreeable melancholy which, of all dispositions of the mind is the best suited to love and friendship'. ${ }^{27}$ We would learn to be more selective in our choice of friends and we would come to love and respect those we had more highly. 
Hume's idea of a private world in which ease, happiness and moral autonomy could be acquired is more complex than Addison's. He was to become increasingly impatient with agreeable Addisonian 'trifflings' ${ }^{28}$ and with the notion of a social world which revolved around aimless and trivial conversation. The job of the philosopher was to serve as an ambassador from the learned to the conversable world in order to elevate its conversation and direct it to the sort of moral and political questions that were integral to the Science of Man and to the cultivation of virtue. At the same time he would learn from the conversable the sort of lessons which Hume said he had learned from ordinary men while writing the Treatise - how to curb unnecessary credulity or pyrrhonism with common sense and how to respect the natural beliefs of ordinary men. ${ }^{29}$ This symbiotic relationship between the learned and conversable world would render philosophy useful to society and society of use to the philosopher. It was, moreover, a symbiosis which had only become possible in the modern age in the company of men of middling rank who were rich enough to be independent of the great; sufficiently leisured and literate to be able to relish the delights of studying human nature; sufficiently independent-minded to distrust the authority of received opinion; sufficiently practical to be able to reason from experience rather than final causes. Such men were unknown in gothic times when society was dominated by warlike barons, fanatical priests and a servile peasantry. As Harrington had observed, it was only with the passing of feudalism and the rise of monarchies, systems of laws, luxury and commerce that a middling class of men had come into their own. ${ }^{30}$ Thus it was only in the modern age that it had at last become possible to envisage a true science of man and a system of morality which would rest on the principles of human nature and help to underpin the liberties and happiness of the citizens of modern civil society.

It was from the tightly knit, good humoured, sophisticated coteries of literati that met in the coffee-houses and taverns of an Addisonian world that Hume thought the new science 
and the new morality would emerge. Here they had

\begin{abstract}
A better chance for achieving a knowledge both of men and things than those of a more elevated station in life and everything appears in its natural colours before him; he has more leisure to form observations; and has, besides, the motive of ambition to push him on in his attainments, being certain that he can never rise to any distinction or eminence in the world, without his own industry. ${ }^{\mathbf{3 1}}$
\end{abstract}

But it was to the importance of conversation in forging and maintaining the friendship on which social life depended that Hume continually returned. It was conversation, that 'mutual deference or civility, which leads us to resign our own inclinations to those of our companion, and to curb and conceal that presumption and arrogance so natural to the human mind' ${ }^{32}$ that art which was unknown to the ancients and was as yet ill-cultivated by the moderns $;^{\mathbf{3 3}}$ it was conversation that made social life and the acquisition of moral principles possible. It was through conversation that men were exposed to the general principles of taste and morals upon which their ordinary understanding of life depended. It was from conversation with ordinary men that philosophers learned to 'consult experience', searching for it 'where it is alone to be found, in Common Life'. ${ }^{34}$ And it was through conversation that philosophers could learn to temper their sceptical paradoxes with respect to those natural beliefs which guide men through everyday life. It did not matter, said Hume, whether one was an epicurean, a stoic or a sceptic by temperament; whether one found it more agreeable to be governed by the senses, by a love of hard work or by an instinctive distrust of the moral and intellectual authority of others. Provided one regarded the end of life as an ease, contentment and a sense of ego; provided one realized that the senses, hard work and scepticism must each play their part in forming one's moral character, one might achieve wisdom and virtue. ${ }^{35}$ It was a lesson which could only be learned in the company of 
friends and it was a lesson which would inform one's sense of moral and civic duty.

The tone of Hume's discussion was Ciceronian but it is Cicero underpinned by Humean scepticism and adapted to the social needs of a modern age. Cicero had written in a stoic spirit about civic virtue and the philosophical and political virtues of acquiring a lofty detachment from men, ideas and fortune. It was only thus that a statesman could distance himself from the pressures to which the great men who direct affairs are inevitably subjected. But Hume did not write for statesmen. His audience was composed of men of middling rank who had an active interest in public affairs but possessed neither the means nor the desire to be great statesmen. It would be foolish for such men to take the letter of Ciceronian stoicism too seriously. But equally, it would be foolish of them to ignore the spirit of his teaching. For Cicero's teaching could be used to create a new political class whose members had learned collectively to appreciate the values of stoic detachment. Paradoxical though it might seem, Ciceronian stoicism and Addisonian sociability were by no means incompatable. In the process, conversation, the supreme instrument by which friendships were created and maintained and philosophy improved, had become as important to the maintenance of virtue in Hume's world as eloquence was in that of Cicero. ${ }^{\mathbf{3 6}}$

I have discussed Hume's moral preoccupations like this because I believe that they were of central importance to his philosophical development and that they arose quite naturally from that protean masterpiece the Treatise. It is also important to remember that it was only after he had completed his exploration of the problems of civic morality that he felt able to return to the central principles of the Treatise. The two Enquiries of 1748 and $175^{1}$ are remarkable and undervalued discussions of the principles of human nature and morals by a practical moralist anxious to instruct his readers in the principles of virtue. Every metaphysical or historical question which had been discussed in the Treatise was carefully stripped away or relegated to appendices if it was irrelevant to his 
moral teaching. ${ }^{37}$ The conclusion to the second Enquiry contains Hume's final statement of his principles of civic morality. Moral behaviour is only possible in society and the foundation of all social life is the rules of justice. Our natural disposition is to submit to the authority of established rules and to acquire the beliefs and prejudices of those like ourselves. Our desire to acquire a sense of virtue will encourage us to look for an independence from the authority of received ideas by testing their credibility against the facts of experience. Our desire for ease, virtue and an active, useful life will prevent us from allowing our scepticism from degenerating into an absurd and enervating pyrrhonism.

How little is requisite to supply the necessities of nature. And in view to pleasure, what comparison between the unbought satisfaction of conversation, society, study, even health and the common beauties of nature, but above all the peaceful reflection one's own conduct: what comparison, I say, between these and the feverish empty amusements of luxury and expense? These natural pleasures, indeed, are really without price; both because they are below all price in their attainment and above it in their enjoyment. ${ }^{38}$

It was a conception of civic virtue that could be learned and practised in the coffee-house and in the salon. For, as Hume remarked, 'why in the greater society or confederacy of mankind, should not the case be the same in particular clubs and companies'. ${ }^{39}$

Historically speaking, the consequences of Hume's emergence as a civic moralist were of some importance to the development of Scottish culture. He had adopted a mode of philosophizing that was in itself of great importance to the Scots and it allowed Edinburgh's social and literary élite to treat him with the respect that any society accords to a man whose work is deemed to be of public importance. It was as a civic moralist rather than as a religious sceptic that he quickly became a key figure in the organization of the city's cultural 
life. He was a founder member and an active patron of the Select Society, secretary of the Philosophical society and his patronage was eagerly sought by lesser societies. It was because they shared Hume's views about the role of philosophers and philosophizing in a modern age that moderate ministers and laymen fought successfully to rescue Hume and his kinsmen Lord Kames and John Home from the charges of infidelity which had been levelled against them by the orthodox wing of the General Assembly of the Scottish kirk. By the early I 760 's he was generally looked on as one of the leaders of taste and learning in the city. His conversation was enjoyed by young and old alike and reported with care and he was looked on with approval even by those who were disturbed by his religious scepticism; for his literary reputation reflected credit on the city. By the end of his life his own literary reputation and that of Edinburgh were closely connected and when foreigners like Johnson or Gibbon, Franklin or Jefferson thought of Edinburgh, Hume's name was one of the first to spring to mind. The consonance of his views about civic morality with those of a distinctive social and literary élite was a necessary precondition of his social and intellectual pre-eminence in the city. It was for the same reason that those who enjoyed his company found it possible to neutralize the problems caused by his notorious infidelity by an agreement to differ which occasionally had to be spelled out in no uncertain terms. But scepticism was, for an increasing number of Scotsmen outside the charmed circles of the Edinburgh élite, a cuckoo which was already growing dangerously fast. For an Aberdonian moralist like James Beattie, Edinburgh had become part of a Castle of Scepticism which was sapping the self-confidence of young men destined for a life in the world of public affairs, destroying religion, morality and virtue. ${ }^{40}$ It was because Humean scepticism had been legitimized by Edinburgh's élite that it acquired the capacity to arouse the hostility of moralists like Dugald Stewart and Adam Ferguson as well as James Beattie, who were, in their own ways as concerned with civic virtue as Hume had been. As such, it 
was to become one of the most potent forces shaping the intellectual development of Scotland in the age of the Enlightenment. ${ }^{41}$

\section{NOTES}

1 I am grateful to David Fate Norton, Harry Bracken, Charles Robertson and Richard Teichgraeber for comments on an earlier draft of this paper.

${ }^{2}$ See, in particular, Donald F. Bond's introduction to his edition of the Spectator (Oxford, I965) I, xiii-cix, and Peter Gay 'The Spectator as Actor: Addison in Perspective' Encounter, xxix, no. 6, December 1967 , pp. 27-32.

3 'I am a Fellow of a very odd Frame of Mind' Spectator no. I67. 'Cast of Mind' is used in the same sense in Spectator, no. 225. See also Spectator, no. 634. Mrs. Hutchinson had used the expression 'Frame of Spirit' in a roughly analogous sense in 1665 . OED Frame.

${ }^{4}$ See my 'Culture and Society in the I8th Century Province: the case of Edinburgh and the Scottish Enlightenment' in The University in Society, ed. L. Stone (Princeton, 1974), ii, pp. 407-48.

5 Ibid.

${ }^{6}$ I shall develop this point at length in my forthcoming study of the Scottish Enlightenment The Pursuit of Virtue. See also J. G. A. Pocock, Politics Language and Time (New York, I97 I), ch. 3 .

7 E. G. Mossner, 'Philosophy and Biography: the Case of David Hume', Philosophical Review, 59 (1950).

8 Boswell in Extremes $1776-1778$, ed. C. M. Weiss and F. A. Pottle (New York, I970), p. I I.

The Letters of David Hume, ed. J. Y. T. Greig (Oxford, 1952), I, p. Io.

10 Peter Gay was the first scholar to point out the central importance of Cicero to the thought of the Enlightenment. See his The Enlightenment: an Interpretation. The Rise of Modern Paganism (London, I966), esp. pp. 105-9.

11 E. C. Mossner The Life of David Hume (Edinburgh, I954), p. I $2 \mathrm{I}$.

12 Sheldon Wolin, Hobbes and the Epic Tradition of Political Theory (Los Angeles, 1970).

13 'Upon the whole, I desire to take my Catalogue of Virtues from Cicero's Offices, not from the Whole Duty of Man. I had 
indeed, the former Book in my Eye in all my Reasonings.' Letters of David Hume, i, p. 34. See also Letters, i, p. 16.

${ }^{14} A$ Treatise of Human Nature, ed. L. A. Selby Bigge (Oxford, I967), p. 269 .

${ }_{15}$ Treatise, p. 2 I 8 . See also J. Noxon, Hume's Philosophical Development (Oxford, I973), pp. 8-16.

16 Treatise, p. 269.

17 That is not to say, of course that Addison regarded society as the prime cure for philosophical scepticism. That important role was reserved for religion. But society certainly was a cure for lesser ailments. See, for example Spectator, nos. 93 and 222. Hume, in his characteristically unnerving manner, simply saw no reason why greater and more profound ailments should not be cured in the same way as more trivial ones.

${ }^{18}$ E. C. Mossner, Life of David Hume, pp. $13^{8-9}$.

19 The order in which the essays were originally published is as follows. Volume I. I. Of the Delicacy of Taste and Passion. 2. Of the Liberty of the Press. 3. Of Impudence and Modesty. 4. That Politicks may be Reduced to a Science. 5. Of the First Principles of Government. 6. Of Love and Marriage. 7. Of the Study of History. 8. Of the Independency of Parliament. 9. Whether the British Government Inclines more to Absolute Monarchy or to a Republick. 10. Of Parties in General. 11. Of the Parties of Great Britain. 12. Of Superstition and Enthusiasm. 13. Of Avarice. 14. Of the dignity of Human Nature. I5. Of Liberty and Despotism. Volume II. I. Of Essay Writing. 2. Of Eloquence. 3. Of Moral Prejudices. 4. Of the Middle Station of Life. 5. Of the Rise and Progress of the Arts and Sciences. 6. The Epicurean. 7. The Stoic. 8. The Platonist. 9. The Sceptic. Io. Of Polygamy and Divorces. I I. Of Simplicity and Refinement. I2. A Character of Sir Robert Walpole.

Hume continually regrouped and reorganized his essays later in life, omitting some, adding others. T. E. Jessop, A Bibliography of the Works of David Hume ... (London, 1938), pp. 15-18.

20. The importance Hume attached to his argument is emphasized by D. Forbes, Hume's Philosophical Politics (Cambridge, r975), esp. Part I. My views on the ideological significance of Hume's position are slightly different from his.

21 This was a thoroughly Shaftesburian position to take. Anthony, Earl of Shaftesbury. Characteristics of Men, Manners, Opinions, Times. ed. J. M. Robertson (Library of Liberal Arts), i, p. 74. In this, as in so much else, Hume's implied critique of Addisonian morality takes the form of going back to the Shaftesburian sources in which it was founded. 
22 'That Politics may be reduced to a Science'.

${ }^{23}$ Fletcher deserves better treatment from historians than he has so far received. But see J. G. A. Pocock, Politics, Language and Time, ch. 4 and The Machiavellian Moment Florentine Political thought and the Atlantic Republican Tradition (Princeton, 1975), pp. 426-31. See also my 'Culture and Society in the Eighteenth Century Province'.

24 The Political Works of Andrew Fletcher (London, 1737), pp. 445-6.

${ }^{25}$ See, for example, J. Brooke and L. B. Namier, The House of Commons $1754^{-1790}$ (London, I964), i, pp. I69-7o.

${ }^{26}$ The unfruitful debate about Hume's supposed toryism has recently been fully and critically discussed by D. Forbes, Hume's Philosophical Politics, ch. 5-6.

27 'Of the Delicacy of Taste and Passion'.

${ }^{28}$ The Letters of David Hume, ii, p. 257.

29 'Of Essay Writing'. Hume withdrew this essay in the second and subsequent editions of his essays.

30 'Of the Rise and Progress of the Arts and Sciences' and 'Of the Middle Station in Life'. This essay was also withdrawn after the first edition. Hume's general point was to be developed in the economic essays and in the History of England.

31 'Of the Middle Station in Life'. Norah Smith has pointed out the striking similarities between Hume's general treatment of the subject and Addison's. 'Hume's Rejected Essays'. Forum for Modern Language Studies, 8 (1972), pp. 354-7I.

${ }_{32}$ 'Of the Rise and Progress of the Arts and Sciences'.

33 Ibid.

34 'Of Essay Writing'.

${ }^{35}$ For an interesting though rather different discussion of these essays, see David Hume: Writings on Economics ed. E. Rotwein (Edinburgh, 1955), pp. xcv-xcix.

${ }^{36}$ See particularly 'Of the Rise and Progress of the Arts and Sciences' and 'Of Eloquence' for Hume's most conspicuous hints on this subject. As Sheldon Wolin points out, Cicero saw clearly the value of friendship as an instrument of political strategy as well as of private virtue. Politics and Vision: Continuity and Innovation in Western Political Thought (London, I961), pp. 86-7.

${ }^{37}$ J. Noxon, Hume's Philosophical Development, pp. 18-19.

38 Humes Enquiry Concerning Human Understanding and An Enquiry Concerning the Principles of Morals ed. L.A. Selby Bigge (Oxford I902), pp. 283-4.

39 Ibid. $28 \mathrm{I}$.

40 See my 'James Beattie and the Defence of Common Sense' in Festschrift für Rainer Gruenter, ed. B. Fabian (Heidelberg, 1978) pp. 145-54. 
41 See my 'Towards a Definition of the Scottish Enlightenment' in City and Society, ed. D. Williams and P. Fritz (Toronto, 1973,) pp. $125-47$. 